are now nearing completion. The work on nutrition problems in forest nurseries is being carried out by Dr. E. M. Crowther, of Rothamsted, and by his staff, in co-operation with the Commission's research officers, and is under the guidance of a committee presided over by Prof. F. T. Brooks. The work of the forest research officers of the Commission is described in Part 1 under the headings of studies of growth, pathology, entomology, genetics, forest ecology, the treatment of seed, experimental work in the nursery, afforestation of peat, planting experiments on lowland heaths, provenance studies, arboreta and forest gardens. In the introduction Mr. James Macdonald, direetor of research and education, refers with great regret to the sudden death of $\mathrm{Dr}$. M. C. Rayner, who did so much valuable research work in connexion with forest nurseries in Great Britain. In Part $3 \mathrm{Mr}$. M. V. Laurie, chief research officer, gives a general note on work that has been undertaken during the year, such as soil faunal investigations, research into the physical and chemical properties of forest soils, forest soil investigations in Scotland, researches in soil mycology, investigations on Fomes annosus attacks in East Anglian pine plantations, botanical studies on tree races and forest ornithological investigations.

\section{The American Naturalist}

TнE American Naturalist, which was established in 1867, has become, beginning with the eightyfifth volume, the journal of the American Society of Naturalists and will be issued six times a year by the Science Press, Lancaster, Pennsylvania. Dr. L. C. Dunn, of Columbia University, has been appointed managing editor, and an editorial board, consisting at present of Prof. G. E. Hutchinson (Yale University), Prof. Thomas Park (University of Chicago), Dr. G. L. Stebbins (University of California) and Prof. Conway Zirkle (University of Pennsylvania), is in process of formation. The policy of the journal will be to continue its service to general biologists and naturalists in correlating the various biological sciences by the publication of essays, addresses, and symposia of biological societies; space will also be given to reports of new research, preference being given to those in which the chief inherent interest is in theoretical interpretation and synthesis. Editorial material should be sent to the editor of the American Aaturalist, Box 2 , Schermerhorn Hall, Columbia University, New York 27, N.Y.

\section{Foreign Scholarships for British Students}

THe British Council has published a list of some seventy scholarships for the academic year 1951-52 offered by fifteen foreign governments and universities to British students. Although mainly for postgraduate study, some scholarships are open to those not yet graduated and to those with nonacademic professional qualifications. They provide free tuition and maintenance, and the majority are tenable for the complete academic year, with a few for shorter periods. The countries concerned are: Austria, Belgium, Brazil, Denmark, Finland, France, Germany, Italy, the Netherlands, Norway, Persia, Portugal, Spain, Sweden and Switzerland. The scholarships in most cases correspond to those offered by the British Council to foreign students from these countries, and the list is not therefore comprehensive of all the scholarships that are tenable abroad by British students. Closing dates for applications vary for each country, the earliest being
March 7. Details of these scholarships are contained in a booklet of forty-six pages, issued by the British Council, which is remarkable for its comparative lavishness, particularly in the use of space; thus a certain address, spaced out into five lines of print, is repeated no less than eighteen times. Presumably all this information is for circulation in Great Britain only, and duplicated typescript sheets might have served. The booklet and application forms for scholarships are obtainable from the British Council at 65 Davies Street, London, W.1, or at any one of its regional and area offices.

\section{Nuffield Foundation Awards in Dentistry}

To help the advancement of teaching and research in dental health and disease, the Nuffield Foundation is offering a number of fellowships to enable men and women with dental qualifications to receive additional training in pure and applied science that will fit them for an academic career in dentistry, and also to enable university graduates in medicine and science to receive training that will qualify them to undertake teaching and fundamental research on dental health and disease; in the latter case, it is not expected every fellow will necessarily study to obtain a registrable dental qualification, and the Foundation hopes that there will be an increased number of applicants for this type of fellowship as compared with the disappointing response of last year. The annual value of all the fellowships is $£ 500-800$, and they will be awarded for one to three years. Scholarships, normally tenable for one year, are also available for students at university dental schools in the United Kingdom; these scholarships cover tuition fees and include a subsistence allowance of not more than $£ 200$ a year. Application forms for fellowships must be returned by March 1, and for scholarships by June 30 ; these forms are obtainable from the secretary of the Nuffield Foundation, 12 and 13 Mecklenburgh Square, London, W.C.I.

\section{Summer School on Social Biology and Health}

A SUMmer school on "Social Biology and Health" will be held at Wadham College, Oxford, during August 20-September 3. The School is intended for all who are interested in public and personal health and for teachers of pre-nursing courses and biologists taking non-academic courses in sixth forms, as well as for lecturers in health education in training colleges and health visitors. Miss P. M. Taylor, of Homerton College, Cambridge, president of the Association of Women Science Teachers, and Mr. L. J. F. Brimble, chairman of the British Social Biology Council, will direct the School. Among those who have already agreed to take part are Prof. Fred Grundy, Mansel Talbot professor of preventive medicine in the Welsh National School of Medicine, Cardiff; Dr. J. L. Burn, medical officer of health, Salford; Dr. Hugh Sinclair, director of the Lab. oratory of Human Nutrition, Churchill Hospital, Oxford; Sir Thomas Dalling, of the Ministry of Agriculture and Fisheries Veterinary Laboratory at Weybridge; Dr. Josephine Macalister Brew, educational adviser to the National Association of Girls' Clubs and Mixed Clubs; Dr. Celia Westropp, physician-in-charge of the Child Health Survey, Institute of Social Medicine, Oxford; Dr. Lee, vicar of the University Church; Mr. W. Combey, chief sanitary inspector, Oxford; and $\mathrm{Mr}$. $\mathrm{R}$. Weatherall, editor of Biology and Human Affairs. Lectures will cover a wide variety of topics, including 